\title{
Characterization and Rate of Rice Husk Application for Crop Production.
}

\author{
Essoka, A. N; Essienetok, E. U; *Essoka, P. A. and Agba, O. A. \\ Department of Agronomy, Cross River University of Technology, Obubra Campus. *Department of Geography \\ and Environmental Sciences, University of Calabar, Calabar.
}

\begin{abstract}
To avoid environmental nuisance, mankind faces the challenge of managing the large quantities of waste produced by modern agriculture. In Nigeria, huge rice husk dumps are commonly found around rice mills. Fresh rice husk were used as manure in "fertilizing" loamy sand soil at the rate of 0, 20, 25, 30,35, 40, 45, 50, 55, and 60 tonnes per hectare. The experiment was laid in a Randomized Complete Block Design in 2007 and 2008. In 2007, there was a general trend of plant height increasing from zero treatment to 35 t/ha after which fluctuations set in. The mean plant height fluctuated more in 2008 though the different rates of application were significantly different. The optimum application rate to obtain best plant height at 4 and 6 weeks after planting was obtained at 30t/ha. The optimum yield of 2.02t/ha was obtained in 2007 from fields manured with 40t/ha. In 2008, the optimum yield of 2.18 t/ha was obtained from fields manured with 35t/ha. Characterization of the rice husk showed that they were very rich in organic carbon, total nitrogen, available phosphorus, and the exchangeable bases especially calcium and magnesium. Where the husk $\mathrm{pH}$ was extremely acid (4.1), the exchangeable acidity was correspondingly high (16.8) compared to where the pH was slightly acid (6.5) with an exchangeable acidity of $0.22 \mathrm{cmol} / \mathrm{kg}$. Some chemical properties of the soil increased (e.g. P) after harvest i. e. more than what was found before cultivation while other properties remained similar to contents found before cultivation showing little or no depletion at the end of the cropping season. Apart from guaranteeing average yield, rice husk has the potential of leaving the soil not or slightly depleted. It is therefore a highly sustainable material for crop production and maintaining soil health.
\end{abstract}

Key words: application rate, characterization, crop yield, rice husk.

\section{Introduction:}

Modern agriculture generates large quantities of waste during processing. FAO [1] reported that over 1.5 million metric tonnes of rice mill wastes are produced in West Africa. This waste constitutes nuisance to the environment if not properly managed. In Nigeria, since husk dumps are commonly found around rice mills, during the harmattan (dry season) the rice husk dust is carried by wind to contaminate the environment. During the rainy season, leachate from such dumps contaminates surface and ground water. Schoeneich [2] associated the mineralization of ground water in Poland, in addition to other sources, with increased nitrate levels from 3.5 $\mathrm{mg} / \mathrm{l}$ in the sixties to $6.0 \mathrm{mg} / \mathrm{l}$ in 1974. Anikwe[3] used rice husk dust (RHD) to ameliorate the physical properties of clay soils. He found out that RHD increased total porosity, saturated hydraulic conductivity, reduced bulk density and penetration resistance. Nnabode and Mbagwu [4] noted that the initial rate of water entry in to the soil was extremely high particularly on the plots that received higher rates of amendments of fresh rice husk. According to Sanchez and Miller [5]crop residues are suitable in soil structure management and improvement, in protecting the soil surface and the maintenance of continuous transmission pores through the profile.

Tester [6] concluded that organic fertilizer contributes greatly to the water holding capacity of the soil. The use of organic materials to improve soil properties is obvious. Young [7] reported that water holding capacity of the soil dropped from $57 \%$ to $37 \%$ when soil organic matter dropped from 5\% to 3\%. Use of organic waste as bio-fertilizer is beneficial to crops because of the nature of release into the soils of elements like nitrogen, calcium, phosphorous, magnesium, potassium, etc. Also, there was increase in the exchangeable calcium and magnesium from 0.07 to $1.8 \mathrm{cmol} / \mathrm{kg}$ and 0.4 to $1.4 \mathrm{cmol} / \mathrm{kg}$ respectively in swine waste and cow dung amended soils[8]. Hartz et al [9] reported that compost made from organic wastes when applied to the soil, increase soil organic matter and supplies plants nutrients slowly over time. Lekassi [10] stated that the use of organic materials in soil, maintain moisture levels considered favourable for plants growth. The use of organic amendments in soil had resulted in the decrease of phosphorous fixation thereby enhancing phosphorous availability [11]. Solomon and Ogeh [12] reported an increase in crop yield and soil nutrient status when Calapogoniummuconoides, rice husk and Centrosemapubescens were used as compost materials compared to the control. Okpara and Mbagwu [8] recorded an increase in maize yield when cow dung and swine wastes were used as treatment over control. Mucheru et al [13], obtained increase in maize yield of 4.1 tonnes per hectare 
when the soil was treated with cattle manure over control. They also recorded increase in maize grain yield over control when Crotalaria, Calliandra and Leucaena were used as soil amendments.

Many waste products from agricultural processing are known to be beneficial in improving soil fertility. However the characterization and especially the rates of application of such organic wastes are such important information that are still scanty for different crops. This paper therefore examines and reports the characteristics of rice husk and what rates could be used to obtain optimum maize production without any supplementary inorganic fertilizer.

\section{Materials And Methods:}

This research was conducted at the Cross River University of Technology, Obubra Campus, Cross River State, Nigeria in 2007 and 2008. Mean annual rainfall of the area is between $2250 \mathrm{~mm}$ and $2500 \mathrm{~mm}$ while temperature is between $21^{\circ} \mathrm{C}$ and $29^{\circ} \mathrm{C}$ [14]. Rice husk was used as organic manure at the following rates 0,20 , 25, 30, 35, 40, 45, 50, 55 and $60 \mathrm{t} / \mathrm{ha}$. Previous trials by Essoka et al [15] with rates below 20t/ha showed that yields kept increasing with increase in rates. Each subplot measured $3 \mathrm{~m}$ by $3 \mathrm{~m}$. The experiment was laid using Randomized Complete Block Design (RCBD) and replicated four times. The dry rice husk from the mill was mixed with the soil according to the treatment. Sowing of maize seeds (TZEE) was done a day after the husk was incorporated into the soil at distance of $75 \mathrm{~cm}$ by $30 \mathrm{~cm}$ giving 44,444 plants per hectare. The field was kept weed free throughout the period of research. Plant height was recorded from two weeks after planting (WAP).Each year before cultivation a composite soil sample was collected from the site, shade dried and sieved using $2 \mathrm{~mm}$ sieve and analyzed for routine analysis [16].

\subsection{Plant Height:}

\section{Results And Discussion:}

Results of mean plant height are shown in Table 1. In 2007 there was a general trend of plant height increasing from zero treatment to $35 \mathrm{t} / \mathrm{ha}$. After this, fluctuations set in. This pattern was repeated in 2008 only at 6 WAP. The mean plant height fluctuated more in 2008 compared to 2007.

Table1. Mean plant height $(\mathrm{cm})$ of maize at different weeks after planting.

\begin{tabular}{lllllll}
\hline $\begin{array}{l}\text { Treatment } \\
\text { t/ha }\end{array}$ & \multicolumn{2}{l}{ Weeks after planting(2007) } & \multicolumn{3}{c}{ Weeks after planting (2008) } \\
& 2 & 4 & 6 & 2 & 4 & 6 \\
\hline 0 & & & & & & \\
20 & 14.69 & 54.59 & 82.34 & 17.88 & 36.94 & 99.34 \\
25 & 18.88 & 91.75 & 138.36 & 17.34 & 44.50 & 115.53 \\
30 & 22.61 & 104.88 & 157.89 & 18.85 & 41.87 & 116.66 \\
35 & 27.19 & 133.22 & 170.21 & 18.20 & 45.51 & 122.75 \\
40 & 28.67 & 124.38 & 187.18 & 17.93 & 49.47 & 139.45 \\
45 & 23.73 & 118.96 & 178.82 & 18.16 & 48.27 & 135.66 \\
50 & 29.43 & 114.96 & 173.05 & 19.06 & 53.53 & 146.66 \\
55 & 25.85 & 114.96 & 182.78 & 17.02 & 54.24 & 151.32 \\
60 & 30.02 & 177.14 & 176.18 & 18.46 & 54.94 & 150.54 \\
LSD & 30.38 & 122.84 & 186.92 & 18.26 & 55.28 & 186.53 \\
\hline
\end{tabular}

However, the results showed that different rates of application were significantly different.

At two weeks after planting, mean height was significant in 2007 but insignificant in 2008. At 4 WAP in 2007 application rate of 30-35t/ha and 60 t/ha were statistically the same which implied application at rates higher than $30 \mathrm{t} / \mathrm{ha}$ will produce similar plant height. In 2008 at 4 WAP showed that increasing rates of application produced better growth though treatments close to each other were very similar in effect. The growth pattern was similar to that of $4 \mathrm{WAP}$ and $6 \mathrm{WAP}$ in both years.

\subsection{Maize Yield}

The result of maize yield is presented in Table 2. All rates of application improved maize yield over the control in both years. In 2007 and 2008 yield fluctuated with increasing application rates of rice husk. However, yield tended to markedly improve from $35 \mathrm{t} / \mathrm{ha}$ rate of application with yields close to or above 2.0 t/ha. Though the plots receiving $55 \mathrm{t} / \mathrm{ha}$ recorded the highest yield of $2.55 \mathrm{t} / \mathrm{ha}$, this was not significantly different from the yields from plots receiving $40 \mathrm{t} / \mathrm{ha}$. Application rates from $20 \mathrm{t} / \mathrm{ha}$ to $30 \mathrm{t} / \mathrm{ha}$ in $2007 \mathrm{had}$ similar yields, all less than $2.0 \mathrm{t} / \mathrm{ha}$. The application rates from $40 \mathrm{t} / \mathrm{ha}$ upwards yielded similar results, generally above $2.0 \mathrm{t} / \mathrm{ha}$. The application rate of $35 \mathrm{t} / \mathrm{ha}$ yielded a little less than $2.0 \mathrm{t} / \mathrm{ha}$ i.e. $1.90 \mathrm{t} / \mathrm{ha}$. 
Characterization and Rate of Rice Husk Application for Crop Production.

Table 2: Mean yield of maize (t/ha)

\begin{tabular}{lll}
\hline Treatment (t/ha) & 2007 & 2008 \\
\hline 0 & 0.36 & 0.80 \\
20 & 1.63 & 1.70 \\
25 & 1.24 & 1.69 \\
30 & 1.29 & 1.82 \\
35 & 1.90 & 2.18 \\
40 & 2.04 & 2.26 \\
45 & 2.36 & 2.12 \\
50 & 2.20 & 2.34 \\
55 & 2.55 & 1.97 \\
60 & 2.34 & 1.82 \\
LSD & $\mathbf{0 . 5 4}$ & $\mathbf{0 . 3 6}$ \\
\hline
\end{tabular}

In 2008 yields (all less than $2.0 \mathrm{t} / \mathrm{ha}$ ) were equally similar for application rates of 20-30 t/ha. The optimum application rate in this year was $35 \mathrm{t} / \mathrm{ha}$. In 2007 it was $40 \mathrm{t} / \mathrm{ha}$ (Table 2). From these results we could conclude that the optimum application rate of rice husk in loamy sandy soils or generally coarse soils like sandy loams is between 35-40t/ha. The corn yield falling around the national average may be attributed to the limitation of the local variety used. It is thought that where hybrid varieties are used yields will correspondingly be higher than these [17].

The soils used in these experiment are markedly deficient in nutrients while the rice husk was richly supplied (Table 3). Thus incorporating the rice husk into the nutrient deficient soil was observed to ameliorate the nutrient status and impact positively on crop yield. After corn harvest in 2007, the soils were analyzed to ascertain the residual nutrients. Results of organic carbon showed that seven samples had contents higher than when the soils were cultivated i.e. positive impact while only two samples had contents less than the in situ. Total nitrogen results showed seven samples having contents that remained almost constant. More amazing was the impact of available phosphorous. After crop harvest, seven plots had their in situ phosphorus tripled and two plots doubled theirs (Table 4). The effects of the amendment on exchangeable K showed that the in situ contents did not fall below three units thus leaving six plots with medium contents and three with low. Magnesium had similar effect with six samples leaving contents not less than or equal to $1.5 \mathrm{cmol} / \mathrm{kg}$. Six samples (plots) had Ca samples with contents not less than $4.0 \mathrm{cmol} / \mathrm{kg}$ and no plot had contents less than $3 \mathrm{cmol} / \mathrm{kg}$ while the exchangeable acidity of the soils remained almost the same (Table 4). The contents of exchangeable Na remained almost constant as if the soil had not been used. With these results both from crop yield and soil properties we could conclude that rice husk is an excellent resource for crop production and soil health sustainability.

Table 3: Physicochemical properties of soils and rice husk used in the experiment before cultivation

\begin{tabular}{|c|c|c|c|c|}
\hline Property & $\begin{array}{l}\text { Soil } \\
2007\end{array}$ & $\begin{array}{l}\text { Soil } \\
2008\end{array}$ & $\begin{array}{l}\text { Rice husk } \\
2007\end{array}$ & $\begin{array}{l}\text { Rice husk } \\
2008\end{array}$ \\
\hline Sand $(\%)$ & 81.7 & 82.3 & - & - \\
\hline Slit $(\%)$ & 5.3 & 14.2 & - & - \\
\hline Clay (\%) & 13.0 & 3.5 & - & - \\
\hline Texture $(\%)$ & Loamy sand & Loamy sand & - & - \\
\hline $\mathrm{pH}$ (water) & 5.32 & 4.8 & 4.18 & 6.5 \\
\hline Organic carbon (g/kg) & 13.2 & 6.0 & 199.1 & 299.2 \\
\hline Total N (g/kg) & 0.4 & 0.5 & 8.7 & 24.7 \\
\hline $\mathrm{C}: \mathrm{N}$ ratio & 33.0 & 12 & 22.9 & 12.11 \\
\hline Available P (mg/kg) & 8.20 & 6.13 & 154.79 & 107.0 \\
\hline Exchangeable $\mathrm{K}(\mathrm{cmol} / \mathrm{kg})$ & 0.17 & 0.14 & 0.64 & 0.12 \\
\hline Exchangeable $\mathrm{Mg}(\mathrm{cmol} / \mathrm{kg}$ & 1.92 & 1.50 & 8.80 & 14.8 \\
\hline Exchangeable $\mathrm{Ca}(\mathrm{cmol} / \mathrm{kg})$ & 4.94 & 3.09 & 20.0 & 31.6 \\
\hline Exchangeable $\mathrm{Na}(\mathrm{cmol} / \mathrm{kg})$ & 0.06 & 0.11 & 0.42 & 0.27 \\
\hline Exchangeable Acidity $(\mathrm{cmol} / \mathrm{kg})$ & 1.60 & 2.24 & 1.68 & 0.22 \\
\hline $\mathrm{ECEC}(\mathrm{cmol} / \mathrm{kg})$ & 8.69 & 7.07 & 31.54 & 47.01 \\
\hline Base Saturation (\%) & 7.72 & 24.55 & 94.67 & 99.53 \\
\hline
\end{tabular}


Table 4: Some chemical properties of the soil after corn harvest in 2007.

\begin{tabular}{|c|c|c|c|c|c|c|c|c|c|}
\hline Treatment (tha) & $\begin{array}{l}\mathrm{pH} \\
(\mathrm{H} ; 0)\end{array}$ & $\begin{array}{l}0 . \mathrm{C} \\
(\mathrm{g} / \mathrm{kg})\end{array}$ & $N(\mathrm{~g} / \mathrm{kg})$ & $\mathrm{P}(\mathrm{mg} / \mathrm{kg})$ & $\mathrm{Ca}(\mathrm{amol} / \mathrm{kg})$ & $\mathrm{Mg}(\mathrm{cmol} / \mathrm{kg}$ & $\mathrm{Na}(\mathrm{cmol} / \mathrm{kg})$ & $\mathrm{K}(\mathrm{cmol} / \mathrm{kg})$ & $\begin{array}{l}\text { EA } \\
(\mathrm{mol} / \mathrm{kg})\end{array}$ \\
\hline 0 & 4.82 & 8.3 & 0.2 & 7.39 & 3.84 & 1.40 & 0.05 & 0.14 & 2.88 \\
\hline 20 & 4.92 & 5.9 & 0.2 & $15.79^{\circ}$ & $5.74^{-1}$ & $2.10^{\circ}$ & $\gamma .05$ & $0.14^{-}$ & $2.40^{\circ}$ \\
\hline-25 & 5.01 & 4.2 & $0.4^{-}$ & 21.39 & $5.20^{\circ}$ & $1.20^{\circ}$ & 0.05 & 0.15 & 2.08 \\
\hline $30^{\circ}$ & 5.17 & 3.9 & $0.4^{-}$ & 23.86 & 3.36 & 1.30 & 0.06 & 0.13 & 1.44 \\
\hline 35 & 4.36 & $1.5^{-}$ & 0.4 & 23.93 & 4.32 & 1.82 & $0.06^{-}$ & $0.15^{-}$ & $1.76^{2}$ \\
\hline 40 & 5.13 & 6.8 & -0.5 & $25.93^{-}$ & $4.28^{-}$ & $1.66^{-}$ & $\gamma .06$ & $0.15^{-}$ & $0.80^{\circ}$ \\
\hline 45 & 5.16 & -6.5 & $0.4^{-}$ & 29.75 & 4.07 & 1.58 & 0.05 & 0.12 & 3.20 \\
\hline $50^{\circ}$ & 5.06 & 4.9 & 0.4 & 29.16 & 3.22 & 1.08 & 0.05 & 0.15 & 1.44 \\
\hline $55^{-}$ & 3.11 & $9.5^{-}$ & 0.5 & 24.13 & 3.24 & 2.00 & $0.06^{-}$ & 0.17 & 1.92 \\
\hline 60 & $5.39^{-1}$ & 2.5 & 0.3 & $25.99^{\circ}$ & $5.00^{-}$ & $1.98^{\circ}$ & $\gamma .06$ & 0.16 & $3.20^{\circ}$ \\
\hline
\end{tabular}

References

[1]. Food and Agriculture Organisation. Land resources potential and constraints at region and country levels. World Soil Resources Report No. 90, (Rome,FAO), 2000

[2]. L. Schoeneich, Deteriorating quality of ground water as a result of application of fertilizers - two case studies from Poland. National seminar on environmental pollution;(Jos, Nigeria,1992), 47-50

[3]. M. A. N. Anikwe, Amelioration of heavy clay loam soil with rice husk and its effect on soil physical properties and maize yield. Science direct - Bioresource Technology, 74, (2) 2000, 169-173.

[4]. P. C. Nnabode, and J. S. C.Mbagwu, Physical and hydraulic changes in a typichaplustult in S. E. Nigeria amended with rice mill wastes. $3^{\text {rd }}$ African Soil Science Society Conference, Ibadan, 1994.

[5]. P. A. Sanchez and R. H. Miller. Organic matter and soil fertility management in acid soil of the tropics, inXIIIth Congress of the International Society of Soil Science, Hamburg, 13-20 August, ISSS - AISS - IBG, 1986, 609-625.

[6]. C. F. Tester, Organic amendment effects on chemical and physical properties of sandy soil. Soil Science Society of America Journal $54,1990,827-831$.

[7]. A. Young, Tropical Soils and Soil Survey,(Cambridge, Cambridge University Press, 1976).

[8]. I.M. Okpara, and J.S.C. Mbagwu, Effectiveness of cattle dung and swine waste as biofertilizers on an Ultisol at Nsukka. Proceedings of the 28th Annual Conference of Soil Science Society of Nigeria, November 4-7, 2003, NRCRI, UmudikeUmuahia, Nigeria,2003, 71-80.

[9]. T. K. Hartz;F. J, Costaand V.Schrander, Suitability of compost and green waste for horticultural uses. Hortiscience 31 (6), 1996, 961-964.

[10]. J. K. Lekasi, Organic resource management in small hold agriculture. Forum for Organic Resource Management and Agricultural Technologies (FORMAT), Nairobi, 2003,1-10.

[11]. N. M. John; G. O.Adeoye, and M. K.C.Sridha,Organic and organo mineral fertilizer: essential tools for sustainable agriculture,Nigerian Journal of Agricultural Technology,7, 1998, 50-57.

[12]. M. G. Solomon and J. S.Ogeh,Use of some leguminous plants and rice husk as fertilizer materials. $3^{\text {rd }}$ African Soil Science Society Conference, 1994, Ibadan.

[13]. M. Mucheru; D. Mugendi, R. Kangai; K. J. Mugwe and A. Mchini, Organic resources for soil fertility management in Eastern Kenya, in E. N.Savala, (Ed.) Organic resources management in Kenya: perspectives and guidelines, Nairobi, FORMAT, 2003.

[14]. Cross River Agricultural Development Programme (CRADP),Report on the wetland soils of Cross River State, Nigeria.,Calabar, CRADP, 1992, 115p.

[15]. A. N. Essoka; E. E Oku and D. O Etta, Response of maize to a loamy sand amended with rice husk at Obubra, South Eastern Nigeria. Global Journal of Agricultural Science,2(1), 2003, 110 - 112.

[16]. International Institute of Tropical Agriculture (I.I.T.A),Selected Methods for Soil Analysis,manual series No. 1. Revised edition. Ibadan, IITA, 1979.

[17]. T. O. Ibia, and E. J.Udo,Guide to fertilizer use for crops in Akwalbom State, Nigeria.Uyo, Ministry of Agriculture and Natural Resources, 2009. 